\title{
Malignant Pleural Effusions: Mistletoe Spray Instead of Talc Poudrage?
}

\author{
Jane A. Shaw Coenraad F.N. Koegelenberg \\ Division of Pulmonology, Department of Medicine, Stellenbosch University and Tygerberg Academic Hospital, \\ Cape Town, South Africa
}

An intervention for the management of malignant pleural effusion (MPE) will perforce be palliative in nature, as no procedure has yet been shown to prolong life in this setting $[1,2]$. In general, only symptomatic patients should be offered interventions, which ought to be tailored to their individual needs [1].

The two most common approaches to MPE are (1) chemical pleurodesis via rigid or semirigid thoracoscopy or intercostal drainage (ICD) with the aim of obliterating the pleural space, and (2) indwelling pleural catheters (IPC) which allow chronic drainage of the pleural cavity and potentially cause autopleurodesis $[1,3]$. Combining IPC with chemical pleurodesis has also recently been explored [4].

There is truly a dearth of high-quality evidence on the therapeutic approach to MPE, and not surprisingly a high degree of variability in the management thereof $[1,5]$. IPC are offered to the majority of patients in some centres (where it has been shown to decrease length of hospital stay), whereas other centres consider chemical pleurodesis to be the first-line therapy in cases without trapped lung and with a life expectancy of $>3$ months [6]. Moreover, in a large multinational series only $51 \%$ were deemed to require definitive treatment [7]. Even fewer received/ required pleurodesis in a large series of mesothelioma patients [8].

More than 20 agents have been used for chemical pleurodesis (mostly via ICD) over the past 80 years, including bleomycin, tetracycline, doxycycline, iodopovidone, and silver nitrate [1]. Many of these substances have been associated with major systemic complications, e.g., pulmonary toxicity with bleomycin, hyponatremia, deranged liver enzymes, subclinical hypothyroidism with iodopovidone, and acute kidney injury and acute respiratory distress syndrome (ARDS) with silver nitrate [5]. The agent most commonly used for pleurodesis, talc, was first introduced in 1935 [9]. Its use has been associated with ARDS, most likely due to the systemic absorption of small-sized talc particles [1]. However, in a multicentre, open-label, prospective cohort study of patients with MPE who underwent pleuroscopy and talc poudrage with calibrated large-particle talc, no patients developed ARDS [10]. Moreover, at least 2 meta-analyses found that nonrecurrence of effusion was more likely with talc than other sclerosants, suggesting that there is little advantage to using other agents over large-particle talc [11, 12]. Only doxycycline has success and complication rates comparable to talc [12].

\section{KARGER}

(c) 2017 S. Karger AG, Basel

E-Mail karger@karger.com

www.karger.com/res
Coenraad F.N. Koegelenberg

Division of Pulmonology, Department of Medicine

Stellenbosch University and Tygerberg Academic Hospital

PO Box 241, Cape Town 8000 (South Africa)

E-Mail coeniefn@sun.ac.za 
In the present issue of Respiration, Eom et al. [13] describe the use of mistletoe extract as a chemical sclerosant delivered in liquid form in the pleural cavity using a spray catheter during semirigid pleuroscopy. The authors highlight the need for an alternative to talc, particularly when a semirigid scope is employed, as it may be challenging to spray graded talc through the $2.8-\mathrm{mm}$ sized working channel. An important additional advantage is the cost: talc poudrage administered via a thick guide sheath during semirigid pleuroscopy costs USD 357 in South Korea (USD 214 for $4 \mathrm{~g}$ of talc and USD 143 for the thick guide sheath kit), compared to USD 56 for the mistletoe extract pleurodesis using a spray catheter (USD 56 for $60 \mathrm{mg}$ of mistletoe extract and USD 0 for the reusable spray catheter). Inherent anticancer effects of the mistletoe extract were also highlighted.

In the present study, consecutive patients with symptomatic MPE who underwent semirigid pleuroscopy from October 2015 to September 2016 were retrospectively analysed. The authors used the radiological outcome at 4 weeks to gage success. Complete response after this rather short follow-up was defined as no reaccumulation of the effusion, and partial response as asymptomatic reaccumulation of the MPE to less than $50 \%$ of the pretreatment effusion. Complete response was seen in $49 \%$ of patients, with a further $44 \%$ experiencing partial response. These are modest figures, as most studies on talc poudrage report success rates of $75-90 \%$ at 1 month [14].
The procedures were well tolerated, with fever documented in approximately $50 \%$ of cases but no severe procedure-related complications. It should be noted that the median duration of chest tube placement after pleurodesis was 7 days (IQR: 6-8 days) in patients with a complete or partial response, which could be attributed to the fact that ICD removal was delayed until $<150 \mathrm{~mL}$ drained over $24 \mathrm{~h}$. Furthermore, the authors did not directly report quality of life scores or dyspnoea or pain indices.

Although Eom and co-workers should be applauded for investigating alternatives to talc poudrage, it remains highly unlikely that the mistletoe will "dethrone" talc as the sclerosant of choice. The authors may also have erred toward an overly conservative approach to ICD removal. A previous study found that earlier drain removal at $24 \mathrm{~h}$ following talc pleurodesis (with the benefit of shorter hospitalisation) did not lead to greater recurrence rates compared with drain removal at $72 \mathrm{~h}$ post-talc pleurodesis [15].

Future studies should ideally focus on patient-based outcomes (time spent in hospital, palliation of symptoms, and quality of life), rather than purely radiological endpoints. Ultimately, management should be tailored around the patient's needs and will, and may involve both outpatient IPC implantation and pleurodesis, rather than either intervention alone.

\section{References}

1 Azzopardi M, Porcel MJM, Koegelenberg CFN, Lee YCG, Fysh ETH: Current controversies in the management of malignant pleural effusions. Semin Respir Crit Care Med 2014;35:723-731.

2 Pilling J, Dusmet M, Ladas G, Goldstraw P: Prognostic factors for survival after surgical palliation of malignant pleural effusion. J Thorac Oncol 2010;5:1544-1450.

3 Fortin M, Tremblay A: Pleural controversies: indwelling pleural catheter vs. pleurodesis for malignant pleural effusions. J Thorac Dis 2015;7:1052-1057.

4 Bhatnagar R, Kahan B, Morley A, et al: The efficacy of indwelling pleural catheter placement versus placement plus talc sclerosant in patients with malignant pleural effusions managed exclusively as outpatients (IPCPLUS): study protocol for a randomised controlled trial. Trials 2015;16:48.

5 Koegelenberg CFN, Vorster MJ: Chemical pleurodesis for malignant pleural effusion: how far have we come in 80 years? Respiration 2015;90:355-356.
6 Roberts ME, Neville E, Berrisford RG, Antunes G, Ali NJ: Management of a malignant pleural effusion: British Thoracic Society Pleural Disease Guideline 2010. Thorax 2010; 65(suppl 2):ii32-ii40.

7 Fysh E, Boshuizen R, Bielsa S, et al: An international study of predictors of definitive therapy in patients with malignant pleural effusion. Respirology 2013;18:31.

8 Fysh E, Tan S, Read C, et al: Pleurodesis outcome in malignant pleural mesothelioma. Thorax 2013;68:594-596.

9 Bethune N: Pleural poudrage: new technique for the deliberate production of pleural adhesion as preliminary to lobectomy. J Thorac Surg 1935;4:251-261.

10 Janssen J, Collier G, Astoul P, et al: Safety of pleurodesis with talc poudrage in malignant pleural effusion: a prospective cohort study. Lancet 2007;369:1535-1539.
11 Shaw P, Agarwal R: Pleurodesis for malignant pleural effusions. Cochrane Database Syst Rev 2004;1:CD002916.

12 Clive AO, Bhatnagar R, Preston NJ, Maskell NA, Jones HE: Cochrane corner: interventions for the management of malignant pleural effusions. Thorax 2016;71:964-966.

13 Eom JS, Ahn HY, Mok JH, et al: Pleurodesis using mistletoe extracts delivered via a spray catheter during semi-rigid pleuroscopy for managing symptomatic malignant pleural effusion. Respiration 2017, DOI: 10.1159/ 000481869.

14 Dresler C, Olak J, Herndon J 2nd, et al: Phase III intergroup study of talc poudrage versus talc slurry sclerosis for malignant pleural effusion. Chest 2005;127:909-915.

15 Parulekar W, Di Primio G, Matzinger F, Dennie C, Bociek G: Use of small-bore vs largebore chest tubes for treatment of malignant pleural effusions. Chest 2001;120:19-25. 